\title{
Reduction of cannibalism in pike (Esox lucius) fry by isolation of full-sib families
}

par C. BRY, C. GILLET

Laboratoire de Physiologie des Poissons, I.N.R.A., 78350 jouy-en-josas, France.

Summary. After 50 days of pond culture fewer pike fingerlings (20 to 33 p. 100) were recovered from the mixing of two full-sib families than from isolated families. Growth and survival were influenced by the family effect. Environmental parameters, such as depth and extent of the banks, may also affect growth and survival. Our results indicated that isolating full-sib families and using small, shallow ponds increased the recovery and growth rate of fingerlings.

\section{Introduction.}

Since early work of Colas (1937) on the production of 3 to 7 -week pike fingerlings in small ponds, numerous authors have reported on this extensive culture technique (Huet, 1948 ; Huet and Timmermans, 1958 ; Hiner, 1961 ; Chauderon, 1969 ; Arrignon, 1972 ; Huet, 1976). The lack of precise data on fingerling weight or size often makes comparison of the various results difficult. However, numerical yields usually range from about 50 to 250 fingerlings per $100 \mathrm{~m}^{2}$ (fingerling total length : 50 to $100 \mathrm{~mm}$; mean individual weight : 0.5 to $5 \mathrm{~g}$ ).

Three interrelated factors which are difficult to control limit the efficiency of this type of culture :

1) climatic conditions, especially temperature change ;

2) nature and quantity of available food : zooplankton, invertebrates, fry of other species ;

3) cannibalism.

In extensive or semi-intensive conditions, work has mainly been focused on the availability of food : pond fertilization (Colas, 1938), supply of plankton (Arrignon, 1972 ; Huet, 1976) and of perch fry (Chauderon, 1969 ; Arrignon, 1972),

Cannibalism is common in pike, especially in the fry which even prefer this way of feeding (Chodorowski, 1973). It may be one of the main factors in regulating pike populations (Hunt and Carbine, 1951 ; Kipling and Frost, 1970). After yolk sac resorption, fry at the swimming stage are 12 to $15 \mathrm{~mm}$ long (Wurtz, 1944 ; Franklin and Smith, 1963), and cannibalism may occur as early as at $21 \mathrm{~mm}$ (Hunt and Carbine 
1951). A plentiful supply of adequate food, suited to the sequential nutritional requirements of the pike juvenile, as well as a moderate temperature and low density can reduce the intensity of cannibalism (Buss, 1961 ; Chauderon, 1969 ; Chodorowski, 1973). However, even under the most optimal conditions, cannibalism remains latent and inevitably depends on the size heterogeneity among individuals. Cannibalism can even occur when there is a size difference of about only 20 to 30 p. 100 in total length (Hunt and Carbine, 1951 ; Buss, 1961).

In extensive culture, cannibalism is reduced by using fry of identical age and by draining the pond early ( 4 to 6 weeks after yolk resorption : Colas, 1938 ; Hiner, 1961). It is nevertheless possible to keep high densities of young pike or spawners (200 to $500 \mathrm{~kg} / \mathrm{ha}$ ) during several months and in excellent conditions ( $<10 \mathrm{p} .100$ loss), provided that the size is standardized (Huet, 1972 ; Bry, unpublished data).

We therefore tried to increase size homogeneity by isolating the offspring of the various females and compared the yields given by these isolated full-sib families with the performances of mixed lots made up by mixing two full-sib families. We also attempted to answer the following questions : (i) does a family effect still influence growth 6 to 7 weeks after yolk sac resorption, (ii) can morphological features of the small ponds have an effect on yields?

\section{Material and methods.}

\section{Experimental design.}

The experiments were carried out from March to May 1978 at the "L $L$ aclet " pike culture facility (Conseil Supérieur de la Pêche). Pike females were injected intraperitoneally and immediately after capture with a preparation of partially purified salmon gonadotropin (de Montalembert ef al., 1978a ; Bry et al., 1978). Three females, referred to as $A, B$ and $C$, were used. Ova were inseminated 5 days after the ovulation-inducing treatment using the « 532 » diluent, a dilution ratio (volume of sperm/volume of diluent) of $1: 1000$, and a ratio of approximately 2 between the volume of the ova and that of the diluent (Billard ef al., 1976 ; Billard, 1977 ; de Montalembert et al., 1978b). Ova from females A and B were inseminated with the sperm of the same male, thus establishing two full-sib families. Ova from female $C$ were inseminated with the pooled sperm of 5 males. Eggs were incubated in Zuger incubation jars up to 80 degree-days, then transferred into a fine meshed trough. At about 100 degreedays post-hatching, i.e. approximately at $2 / 3$ of yolk sac resorption, the fry were siphoned from their trough of origin, counted and stocked in 6 grassy ponds measuring $240 \mathrm{~m}^{2}$ $(18 \times 13.5)$ and in 5 measuring $80 \mathrm{~m}^{2}(14.5 \times 5.5)$, with respective depths of 0.2 to $1 \mathrm{~m}$ and 0.2 to $0.6 \mathrm{~m}$. Fry total length was close to $13 \mathrm{~mm}$ and individual weight averaged $12 \mathrm{mg}$. Regardless of the size of the pond, the same stocking density was used: $6 \mathrm{fry} / \mathrm{m}^{2}$ ( 1500 in the $240 \mathrm{~m}^{2}$ ponds and 500 in the $80 \mathrm{~m}^{2}$ ponds). These ponds had been fertilized with organic manure and filled approximately 10 days before stocking. The fry were alloted as follows:

- fry $A: \operatorname{lots} A_{1} / 240, A_{2} / 240, A / 80$;

- fry $B$ : lots $B / 240, B_{1} / 80, B_{2} / 80$; 
- fry $C:$ lot $C / 240$;

- mixed lots, $A B / 240, A C / 240,(A B)_{1} / 80,(A B)_{2} / 80$, composed of equal proportions of two families ( $A$ and $B$, or $A$ and $C$ ).

Fifty days after stocking, i.e. 60 days after hatching and about 45 days after yolk sac resorption, 10 of the 11 ponds were drained and the pike fingerlings counted and individually weighed to the nearest $0.1 \mathrm{~g}$. Each pond was drained and refilled 2 to 4 times, the first drainage providing about 90 p. 100 of the total production. As there was considerable growth during the 1 to 9 days elapsed between the first drainage and the following ones, only the fish taken during the first drainage were used to calculate the average weight and the coefficient of variation of weight as well as the distribution of individual weights.

On the other hand, numerical yields (recovery yield and yield per unit area of surface) were computed from the total number of fingerlings $N$ recovered in each lot. Pike biomass was estimated using $\mathrm{N}$ and the mean weight of pike obtained when the pond was first drained.

Taking into account the results of successive drainages, the absolute error on $\mathrm{N}$ (total number of fingerlings recovered in each lot) was evaluated as 0 to 30 pike for the $240 \mathrm{~m}^{2}$ ponds ( 0 to $10 \mathrm{p} .100$ of the number recovered) and 0 to 5 pike for the $80 \mathrm{~m}^{2}$ ponds ( 0 to 4 p. 100 of the number recovered).

The lot $B / 240$ was drained 8 days after the other ponds; the mean individual weight and the biomass showed a high increase during this extra growth period. Accordingly, those data were not taken into account in comparisons with the other lots and are indicated in brackets in table 1 : The numerical production $(N)$ of this lot was used, nevertheless, since it could be considered, after subsequent observation, as slightly lower than its true value 8 days before, and because it dealt with a full-sib lot and not with a mixed one.

There were no forage fish in the ponds during the whole experimental period.

\section{Statistical analysis.}

The effects of pike origin and of pond type were tested with a 2-factor analysis of variance (factorial pattern with fixed effects) of the lots involved in both pond types $\left(\mathrm{A}_{1} / 240, \mathrm{~A}_{2} / 240, \mathrm{~B} / 240, \mathrm{AB} / 240, \mathrm{~A} / 80, \mathrm{~B}_{1} / 80, \mathrm{~B}_{2} / 80,(\mathrm{AB})_{1} / 80,(\mathrm{AB})_{2} / 80\right)$ after angular transformation of the percentages (table 2). Theoretical survival rates in the mixed lots were computed by averaging the survival rates observed in the corresponding isolated families. Survival rates were compared using either the normal deviation (table 3) or the $\chi^{2}$ test (table 4). Mean individual weights were compared using Student's t-test. The relative variability of individual weight within a given lot was esti mated as the coefficient of variation (ratio of the standard deviation to the mean in p. 100).

\section{Results and discussion.}

The results are shown in table 1 . The numerical production of fingerlings per $100 \mathrm{~m}^{2}$ ranged from 125 (lot $\mathrm{B} / 240$ ) to 337 (lot $\mathrm{A} / 80$ ). The mean weight varied from 


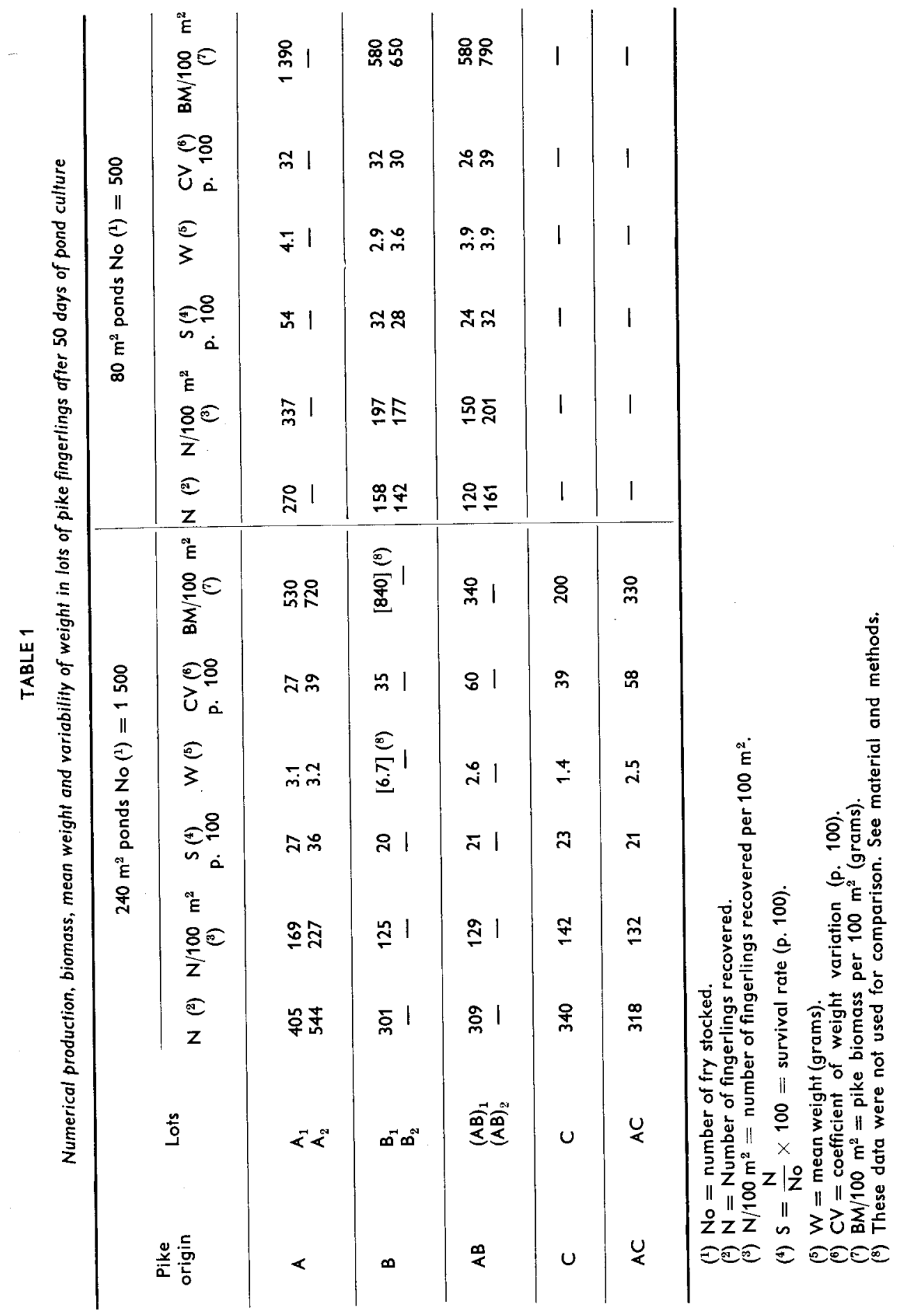


$1.4 \mathrm{~g}$ (lot $\mathrm{C} / 240)$ to $4.1 \mathrm{~g}$ (lot $\mathrm{A} / 80)$, and the biomass per $100 \mathrm{~m}^{2}$ from $200 \mathrm{~g}$ (lot C/240) to $1390 \mathrm{~g}$ (lot A/80), i.e. from 20 to $139 \mathrm{~kg} / \mathrm{ha}$.

These values are, on the whole, somewhat higher than those given by Chauderon (1969) and Huet (1976) who regarded productions over $50 \mathrm{~kg} / \mathrm{ha}$ as exceptional. This suggests that the experimental conditions of our pond culture (pond features, water quality, temperature profile, food availability) were especially favorable.

Analysis of the causes of variation in survival rafe. - The analysis of variance of lots $A, B$ and $A B$ involved in both types of ponds (table 2 ) demonstrated effects of pike origin and pond type and the lack of interaction.

TABLE 2

Analysis of variance : Effect of pike origin and pond type on survival rate after 50 days of pond culture (Lots of the $A, B$, and $A B$ series)

\begin{tabular}{lcccc}
\hline Source of variation & $\begin{array}{c}\text { Degree of } \\
\text { freedom }\end{array}$ & $\begin{array}{c}\text { Mean Square } \\
(\mathrm{MS})\end{array}$ & $\begin{array}{c}F=\text { MS/Resi- } \\
\text { dual MS }\end{array}$ & $\begin{array}{c}\text { Level of } \\
\text { significance }\end{array}$ \\
\hline Pike origin $\ldots \ldots \ldots \ldots$ & 2 & 80.1 & 7.6 & 57 p. 100 \\
Pond type $\ldots \ldots \ldots \ldots$ & 1 & 99.6 & 9.4 & 56 p. 100 \\
Interaction $\ldots \ldots \ldots \ldots$ & 2 & 11.4 & - & (NS) \\
Residual variation $\ldots$ & 3 & 10.6 & - & \\
\hline
\end{tabular}

A residual variance of 9.7 p. 100 relative value was computed between replicate ponds. The high value of this residual variance showed that the differences observed between replicate ponds did not correspond to ordinary sampling fluctuations, but to functional differences between small ponds of similar appearance. Similar observations were made by Buck et al. (1970) who obtained coefficients of variation in survival rate for young carp ranging from 3.3 to 8.5 p. 100 .

TABLE 3

Comparison of survival rates of pike fingerlings : - computed from the data of isolated families (theoretical rates $S_{T}$ ) ; - observed in the mixed lots (experimental rates $S_{E}$ )

\begin{tabular}{|c|c|c|c|c|c|}
\hline & Lots & $\begin{array}{l}\text { Number of } \\
\text { fingerlings } \\
\text { recovered }(\mathrm{N})\end{array}$ & $\begin{array}{l}\text { Survival rate } \\
\text { (p. 100) }\end{array}$ & $\begin{array}{l}\text { Normal deviation and } \\
\text { level of significance of } \\
\text { the difference } \\
\qquad \mathrm{S}_{\mathrm{T}}-\mathrm{S}_{\mathrm{E}}\end{array}$ & $\begin{array}{c}\begin{array}{c}\text { Difference in } \\
\text { survival rates } \\
(p .100)\end{array} \\
\frac{S_{T}-S_{E}}{S_{T}} \times 100\end{array}$ \\
\hline$A B / 240$ & $\begin{array}{l}\text { theoretical } \\
\text { experimental }\end{array}$ & $\begin{array}{l}N_{T}=388 \\
N_{E}=309\end{array}$ & $\begin{array}{l}S_{T}=26 \\
S_{E}=21\end{array}$ & S 1 p. 1000 & 20 \\
\hline$A B / 80$ & $\begin{array}{l}\text { theoretical } \\
\text { experimental }\end{array}$ & $\begin{array}{l}N_{\mathbf{T}}=210 \\
N_{E}=140\end{array}$ & $\begin{array}{l}S_{\mathrm{T}}=42 \\
\mathrm{~S}_{\mathrm{E}}=28\end{array}$ & S 1 p. 1000 & 33 \\
\hline$A C / 240$ & $\begin{array}{l}\text { theoretical } \\
\text { experimental }\end{array}$ & $\begin{array}{l}N_{T}=407 \\
N_{E}=318\end{array}$ & $\begin{array}{l}S_{\mathrm{T}}=27 \\
S_{\mathrm{E}}=21\end{array}$ & S 1 p. 1000 & 22 \\
\hline
\end{tabular}


In our experiment, slight inter-pond variation of such conditions as temperature, flow rate, bottom shape, or other not yet identified parameters, might have created differences in the quality and distribution of pike prey as well as of vegetation, and thus modified survival.

Effect on survival of mixing two full-sib families. - The comparison of the theoretical survival rates computed from the performances of isolated families, and the rates observed in mixed lots (table 3 ) showed a negative mixing effect $(P<0.001$ ) in all cases, which was equal to about 20 to 30 p. 100 of the standing crop.

Analysis of weight distribution. - The weight distributions in isolated lots were generally unimodal and asymmetrical (fig. 1 : lots $A_{2} / 240$ and $C / 240 ;$ fig. 2 : lots A/80 and $\left.B_{1} / 80\right)$. In mixed lots, the weight distributions were bimodal, when the mean weights

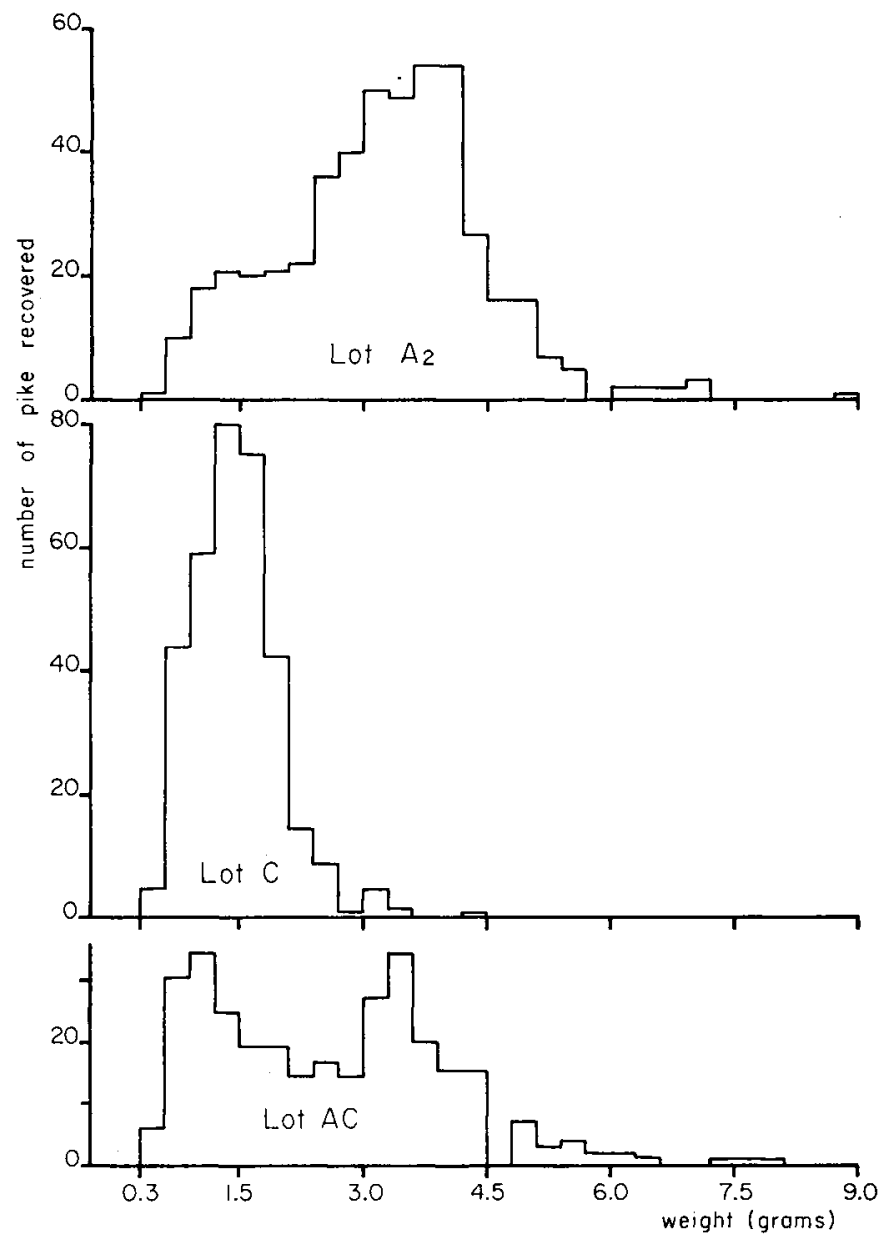

FIG. 1. - Profile of weight distributions within two families (lots $A_{2} / 240$ and $C / 240$ ) and one mixed lot $(A C / 240)$. 
of compound families were sufficiently different (fig. 1 : lot $A C / 240$ ), or they were irregular (fig. 2 ; lot $(A B)_{2} / 80$ ).

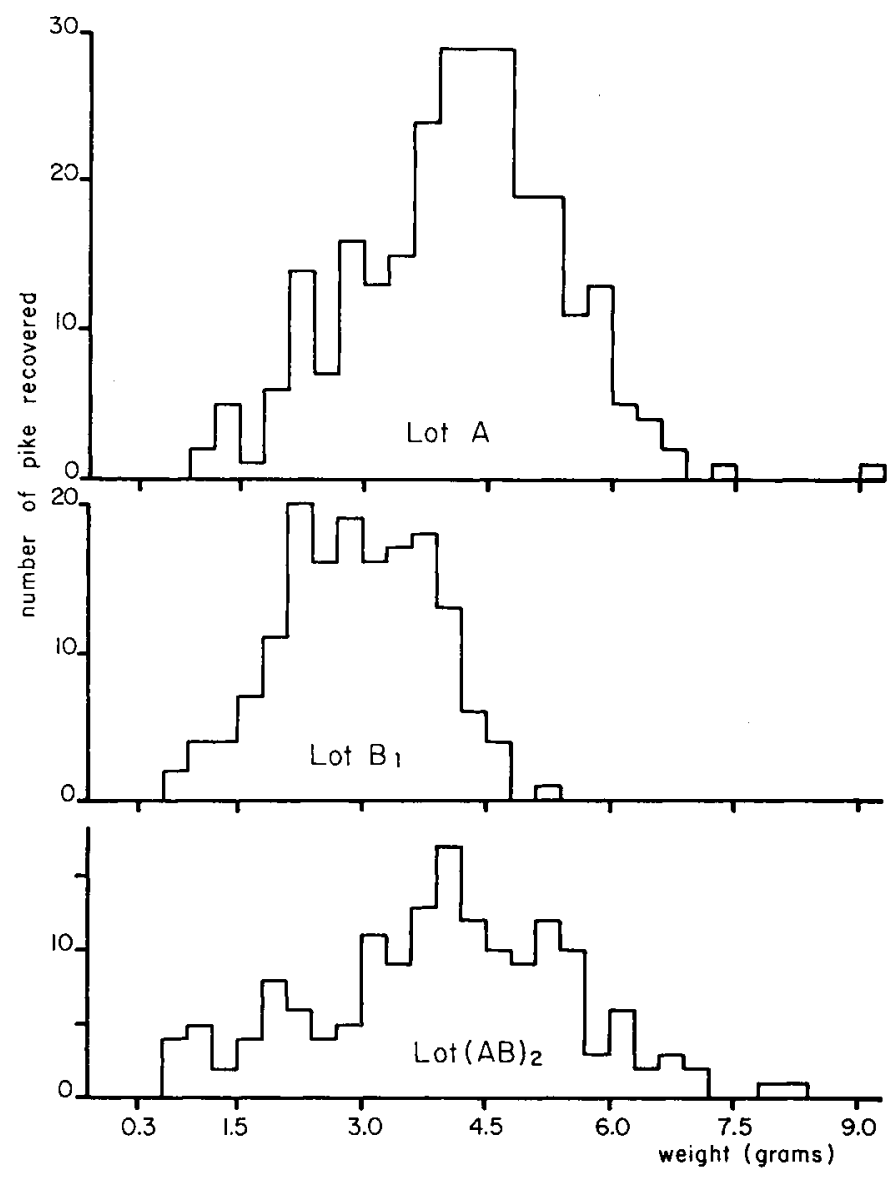

FIG. 2. - Profile of weight distributions within two families (lots $A / 80$ and $\left.B_{1} / 80\right)$ and one mixed lot $\left((A B)_{2} / 80\right)$.

The relative variability of weight (coefficient of variation, table 1) was higher in mixed lots, especially in the $240 \mathrm{~m}^{2}$ ponds where growth was slower : 60 and $58 \mathrm{p}$. 100, as opposed to $27,39,35,39$ p. 100 in isolated full-sib families. The lot $(A B)_{1} / 80$, however had a coefficient of variation lower than that of both components, but survival was especially low in that lot.

Finally, when weight distributions in experimental mixed lots and in theoretical lots were compared, a general although non-significant tendency towards fewer individuals in the low weight class was noted.

These observations suggest that cannibalism intensity was highest where growth was most heterogeneous, i.e. in the mixed lots. Although the full-sib families proved to be the most homogeneous, they also showed a considerable range in weight (up to a 
factor of 30 between extreme values). This observation is in close agreement with that of Carbine (1945) for pike and of Moav and Wohlfarth (1973) who described weights ranging from 1.5 to $82 \mathrm{~g}$ in a full-sib family of carp averaging $3.5 \mathrm{~g}$.

Full-sib family effect. - A comparison of the performances of isolated families A, $B$ and $C$ indicated a family factor effect on survival and growth (table 4). The family effect could be considerable : family A growth was twice that of family C. Family A also showed a higher survival rate, so that family $A$ yielded about 3 times as much as family $C$ in terms of biomass : 530 and $720 \mathrm{~g} / 100 \mathrm{~m}^{2}$ as compared with $200 \mathrm{~g} / 100 \mathrm{~m}^{2}$ in $240 \mathrm{~m}^{2}$ ponds, and twice as much as family $B: 1390 \mathrm{~g} / 100 \mathrm{~m}^{2}$ ys 580 and 650 in $80 \mathrm{~m}^{2}$ ponds.

\section{TABLE 4}

Influence of fry origin (Families $A, B, C$ ) on survival rates and mean weights of pike fingerlings

\begin{tabular}{|c|c|c|c|c|c|}
\hline \multirow{2}{*}{$\begin{array}{l}\text { Pond type } \\
\text { Pike origin }\end{array}$} & \multicolumn{3}{|c|}{$240 \mathrm{~m}^{2}$ ponds } & \multicolumn{2}{|c|}{$80 \mathrm{~m}^{2}$ ponds } \\
\hline & A & B & C & A & B \\
\hline Survival rate (p. 100) & 31.6 & 20 & 23 & 54 & 30 \\
\hline$\chi^{2}$ and level of significance..... & \multicolumn{3}{|c|}{$\begin{array}{c}\chi^{2}(2 \text { d.f. })=83.8 \\
\text { S } 1 \text { p. } 1000\end{array}$} & \multicolumn{2}{|c|}{$\begin{array}{c}\chi^{2}(1 \text { d.f. })=81.5 \\
s 1 \text { p. } 1000\end{array}$} \\
\hline Mean weight $\ldots \ldots \ldots \ldots \ldots$ & 3.2 & 一 & 1.4 & 4.1 & 3.2 \\
\hline tand level of significance ........ & \multicolumn{3}{|c|}{$\begin{array}{c}t=38.1 \\
s 1 \text { p. } 1000\end{array}$} & \multicolumn{2}{|c|}{$\begin{array}{l}t=9.2 \\
s 1 \text { p. } 1000\end{array}$} \\
\hline
\end{tabular}

Effect of pond morphology: - Pond morphology had an effect on both survival (table 2) and growth : the mean weight of family A fingerlings increased from $3.2 \mathrm{~g}$ (lots $240 \mathrm{~m}^{2}$ ) to $4.1 \mathrm{~g}$ in lot $\mathrm{A} / 80$ (normal deviation : $10.3 ; \mathrm{P}<0.001$ ). The combination of a higher survival rate and a faster growth rate in the $80 \mathrm{~m}^{2}$ ponds doubled the biomass, when compared to the $240 \mathrm{~m}^{2}$ ponds. The small ponds demonstrated a remarkable productivity : 58 to $139 \mathrm{~kg} / \mathrm{ha}$ in 50 days. The shallower $80 \mathrm{~m}^{2}$ ponds probably were warmer and consequently may have contained more food (plankton and invertebrates).

The perimeter-surface ratio was twice as much in the $80 \mathrm{~m}^{2}$ ponds as in the $240 \mathrm{~m}^{2}$ ones, and the number of fry per meter of bank was therefore twice as low (12 and $24 \mathrm{fry} / \mathrm{m}$ ). As a matter of fact, the banks might serve as an area of perferred shelter for the pike and their prey.

\section{Conclusions.}

Survival of pike fry cultured for 50 days in ponds was 20 to 33 p. 100 lower when two full-sib families were mixed than when the full-sib families were cultured separately. This difference was probably the result of a higher rate of cannibalism in the 
mixed lots, due to a more heterogeneous growth. There was a considerable family effect, especially on growth. Small $80 \mathrm{~m}^{2}$ ponds induced clearly higher survival and growth rates than those observed in the $240 \mathrm{~m}^{2}$ lots. The biomass of pike recovered from the $80 \mathrm{~m}^{2}$ ponds ranged from 58 to $139 \mathrm{~kg} / \mathrm{ha}$. This net production, achieved in 50 days, can be considered as high according to the literature (Huet, 1976).

Our data suggest isolating full-sib families and using small, shallow ponds for the extensive culture of pike fingerlings. The reduction of precocious cannibalism might also prove of interest in the case of intensive culture where the phenomenon may occur as soon as the delay between feeding sessions exceeds $6 \mathrm{hrs}$ (Westers, 1978).

$$
\begin{aligned}
& \text { Reçu en mars } 1979 . \\
& \text { Accepté en aod } 1979 .
\end{aligned}
$$

Acknowledgments. - This work was supported by a grant from le Conseil Supérieur de la Pêche. The authors wish to thank J. P. Cavitte and G. Neveu for providing the pond facilities and G. Burger, F. Clary, M. Levilain, G. Maisse and D. Marie for their assistance.

Résumé. Le mélange de 2 fratries d'alevins de Brochet s'est traduit, à l'issue d'un élevage de 50 jours en étangs, par un déficit numérique de 20 à 33 p. 100 par rapport au taux de survie moyen des composantes du mélange.

II existe un « effet famille » important, à la fois sur la croissance ef le taux de survie. Des paramètres de l'environnement tels que la profondeur des étangs ef l'importance relative des berges sont également susceptibles d'influer sur les rendements numérique ef pondéral de l'élevage. Les résultats obtenus indiquent que l'isolement des fratries d'alevins et l'utilisation de petits étangs peu profonds peuvent permettre d'améliorer la productivité de ce type d'élevage.

\section{References}

ARRIGNON J., 1972. Station expérimentale d'élevage du brochet du vivier du grès. Bull. fr. Pisci., 246, 33-44.

BILLARD R., DEBRUILLE M., GERARD J.-P., DE MONTALEMBERT G., 1976. L'insémination artificielle du brochet. Bull. fr. Pisci., 262, 30-34.

BILLARD R., 1977. Utilisation d'un système Tris-Glycocolle pour tamponner le dilueur d'insémination pour truite. Bull. fr. Pisci., 264, 102-112.

BRY C., BILLARD R., DE MONTALEMBERT G., 1978. Induction de la maturation ovocytaire et de l'ovulation par traitement hormonal chez le brochet. Bull. fr. Pisci., 271, 21-32.

BUCK D. H., THOITS C. F., ROSE C. R., 1970. Variation in Carp production in replicate ponds. Trans. om. Fish. Soc., 1, 74-79.

BUSS K., 1961. Special purpose report, Pennsylvania Fish commission, Benner Spring Fish Res. Stat.

CARBINE W. F., 1945. Growth potential of the northern pike, Esox lucius. Pap. Mich. Acad. Sci., 30, 205-220.

CHAUDERON L., 1969. Pisciculture en étangs des poissons de repeuplement pour les cours d'eau de la deuxième catégorie. Club halieutique interdépartemental.

CHODOROWSKI A., 1973. Quelques problèmes écologiques concernant l'élevage combiné des carnassiers en pisciculture de repeuplement. Ann. Stat. Biol. Besse-en-Chandesse, 7, 235-272.

COLAS H., 1937. Das vorstrecken der Hechte. Fisch. Z., 40, 517-521.

COLAS H., 1938. Das vorstrecken der Hechte. Fisch. Z., 41, 473-475.

FRANKLIN D. R., SMITH L. L., 1963. Early life history of the northern pike (Esox lucius) with special reference to the factors influencing the numerical strength of year classes. Trans. am. Fish. Soc., 92, 91-110. 
HINER L. E., 1961. Propagation of Northern Pike. Trans. Am. Fish. Soc., 90, 298-302.

HUET M., 1948. La production de brochetons. Bull. fr. Pisc., 148, 121-124.

HUET M., 1972. Elevage ef maturation de géniteurs brochets en petits étangs. Verh. int. Ver. Limnol., 18, 1128-1134.

HUET M., 1976. Reproduction, incubation et alevinage du brochet. EIFAC (Eur. Inland Fish. Advis. Comm.). Tech. Pap., 25, 147-163.

HUET M., TIMMERMANS J. A., 1958. Esociculture, Production de brochetons de sept semaines. Trav. Stat. Rech. Eaux et Forêts, série D, 24, 18 p.

HUNT B. P., CARBINE W. F., 1951. Food of young pike, Esox lucius, and associated fishes in Peterson's ditches, Houghton Lake, Michigan. Trans. am. Fish. Soc., 80, 67-83.

KIPLING C., FROST W. E., 1970. A study of the mortality, population numbers, year class strengths, production and food consumption of Pike in Windermere from 1944 to 1962. J. Anim. Ecol., 39, 115-157.

MOAV R., WOHLFARTH G. W., 1973. Carp breeding in Israel, 295-318. In MOAV R., Agriculfural genetics, selected topics. The Hebrew Univ. Jerusalem.

MONTALEMBERT G. de, JALABERT B., BRY C., 1978a. Precocious induction of maturation and ovulation in northern pike. Ann. Biol. anim. Bioch. Biophys., 18, 969-975.

MONTALEMBERT G. de, BRY C., BILLARD R., 1978b. Control of reproduction in northern pike. Am. Fish. Soc. spec. Publ., 11, 217-225.

WESTERS H., 1978. Biological considerations in hatchery design for coolwater fishes. Am. Fish. Soc. spec. Publ., 11, 246-253.

WURTZ A., 1944. Développement, biologie et nutrition des jeunes alevins de brochet. Bull. fr. Pisc., 135, 57-69. 